\title{
REVIEW
}

\section{Modification of the Light Environment Influences the Production of Horticultural Crops}

\author{
Takeshi KUNIGA*
}

Division of Hillside Horticulture Research, Western Region Agricultural Research Center, National Agriculture and Food Research Organization, Zentsuji, Japan

\begin{abstract}
Light is one of the most important factors affecting plant growth. Although photosynthesis has been widely investigated, knowledge remains limited on how the quality of light influences the production of horticultural crops, especially fruits and vegetables. Here, we present a review of recent studies on how modification to light quality influences the production of these crops. The light environment contributes toward sustaining and regulating fruit and vegetable production. And light conditions are increasingly being modified with such artificial light as light-emitting diodes (LEDs), coupled with sheet mulching. These tools are useful for enhancing light-mediated growth and reproduction in plants. Thus, the physiological and biological responses of plants to light must be analyzed to advance our understanding of the molecular mechanisms underlying how light controls plant development.
\end{abstract}

Discipline: Horticulture

Additional key words: environment, growth, LEDs, mulch sheet, reflection, ultraviolet (UV)

\section{Introduction}

For plants that live in seasonally changing environments, the light environment is one of the most important factors influencing plant growth and development. The regulation of plant photosynthesis by light has been long studied. It is well established that light-energy conditions vary across plants. And it is important to match seasonal changes to light with the best time of the year for the growth and reproduction of plants to maximize productivity, in the most adequate light environment possible. Most plants employ various mechanisms to sense and integrate multiple predictive seasonal cues to regulate major developmental shifts that are driven by light.

More than a quarter of a century has passed since climate change was first officially described as a serious problem by the first Intergovernmental Panel on Climate Change (IPCC) assessment; yet, the world is no closer to averting catastrophic climate change (Gross 2015). Many regions are facing global climate change-induced reductions in crop yields (Rosenzweig 2014). In particular, crops must be developed that are tolerant to drought and heat stress, in order to mitigate the negative impacts of predicted global climate change on global agricultural production (Zandalinas et al. 2018). Extensive environmental changes significantly influence the growth performance and quality of various fruits. Several new methods have been proposed to meet market demand for high-quality fruits (i.e., fruits with high sugar content and moderate acidity) to prevent extensive drought stress in citrus plastic mulch sheets under field conditions (Morinaga et al. 2010, Shimazaki \& Nesumi 2016).

Plastic mulch sheets also affect the thermal environment (i.e., the radiative microclimate). Mulching enhances energy efficiency and improves the thermal microclimate (Bonachela et al. 2012). The reflective plastic mulch also improves the light environment. The quantity of light entering the crowns of citrus species above mulch is also improved. The mulch covering also reduces the number of insects in the fields of citrus crops (Mishiro et al. 2009, Kuniga et al. 2013, 2016). Such effects have been detected not only in citrus but also in other fruit crops. Several studies have demonstrated the

*Corresponding author: kuchino@affrc.go.jp

Received 12 December 2018; accepted 14 February 2019. 
beneficial effect of mulching on fruit quality under field conditions (Decoteau et al. 1988, Ju et al. 1999, Layne 2001, Iglesias et al. 2009). These studies confirmed that light is one of the most important factors affecting plant growth, with artificial radiation inducing a variety of responses (Spalding 2003). In this article, we review these effects, and provide insights on the challenges encountered when using mulching and other techniques to integrate fruit cultivation systems with the light environment and other influencing factors.

\section{Composition of light quality}

Light is generally considered to be the most important of all the environmental cues that influence the growth of plants. Photosynthesis is a light-dependent process. As plants are sessile and must intercept light in their environment, they use specific photoreceptors to detect light conditions and optimize photosynthesis to maximize growth. Light is a crucial environmental factor that determines the level of photosynthesis and fruit production, as well as mediating signal transduction in plants.

The light spectrum is generally separated into UV $(<400 \mathrm{~nm})$, visible $(400 \mathrm{~nm}-700 \mathrm{~nm})$, and far-red $(700$ $\mathrm{nm}-800 \mathrm{~nm}$ ). Plants respond to a wide spectrum of light, ranging from ultraviolet (UV) to far-red light (FR), with certain regions of the light spectrum being important for plant growth and development (Folta \& Carvalho 2015). The UV region of the light spectrum is further divided into three categories UV-A (320 nm-400 nm), UV-B (280 $\mathrm{nm}-320 \mathrm{~nm})$, and UV-C (<280 nm). Plants harbor several different photoreceptors that detect incoming light, including UV-B by the UVR8 protein, UV-A/blue light (B) by cryptochromes, phototropins, LOV domaincontaining proteins, and red/far-red (R/FR) light by phytochromes (Kami et al. 2012, Folta et al. 2015). Each family of photoreceptors initiates unique signaling pathways that lead to appropriate physiological changes, with protein degradation playing a central role in the regulation of each pathway. Light signaling in plants is mediated by several protein receptors that activate various signal transduction pathways to regulate lightdependent responses and corresponding gene expression.

The visible region provides useful energy to drive photosynthesis; therefore, this region of the light spectrum is often called "photosynthetically active radiation" (PAR). The main component of PAR determines the rate of photosynthesis. The visible region is approximately divided into blue $(400 \mathrm{~nm}-500 \mathrm{~nm})$, green $(500 \mathrm{~nm}-600 \mathrm{~nm})$, and red $(600 \mathrm{~nm}-700 \mathrm{~nm})$. Chlorophyll $a$ and $b$ are the primary photosynthetic pigments in higher plants that absorb the blue and red light. The green light (near $660 \mathrm{~nm}$ ) is absorbed marginally; in contrast, approximately $90 \%$ of blue and red light is absorbed by the leaves of plants (Terashima et al. 2009). The development and physiology of plants are strongly influenced by blue and red light. The combination of blue and red light is being increasingly used in both research and commercial horticulture, as it represents the most effective short- and long-term photosynthetic wavebands at the leaf level. The absence of these light wavebands (red or blue) causes photosynthetic inefficiency.

Light wavelength is important for both photosynthesis and protein degradation in plant cells. Christians et al. (2018) showed that specific light wavelengths influence the overall level of ubiquitylation of cullin ligases ( $\mathrm{Cul}$ ), which are a family of hydrophobic proteins that provide a wavelength-specific scaffold for ubiquitin ligases. For instance, LED blue light $(450 \mathrm{~nm})$ has little effect on Cull and Cul3 ubiquitylation levels. On the other hand, LED red-light $(660 \mathrm{~nm})$ regulates Cul3, but depends - at least partially — on the activation of the phytochrome B signaling pathway. Thus, the ubiquitylation levels of individual cullins change in response to different light conditions, thus allowing plants to fine-tune their growth and development to a continuously varying light environment. However, red light causes Cul3 (but not Cul1) ubiquitylation levels to increase.

Other studies have demonstrated that multiple wavebands of light affect the growth and nutrient status of plants. Zhang et al. (2018) showed that, compared with white light, purple, blue, red, and a combination of red and blue light increase the biomass of the aboveground part of lettuce to varying degrees. In comparison, green and yellow light inhibit the growth of lettuce. All of these light treatments were applied at a rate of $200 \mu \mathrm{mol} \mathrm{m}^{-2} \mathrm{~s}^{-1}$. The red-blue light combination (4:1) improves the biomass, soluble protein, vitamin $\mathrm{C}$, and total amino acid content of lettuce.

Other wavebands also influence plant growth. For instance, when green light is added to a background of constant red and blue light, petiole elongation and the upward reorientation of leaves are inhibited in Arabidopsis, as observed in the shade. Thus, the green absorbing form of cryptochrome is a photoreceptor that actively limits the green-light-mediated induction of shade-associated transcripts (Zhang et al. 2011). Green light penetrates further into the leaf than either red or blue light. Thus, a strong white light supplemented with additional green light, which is absorbed by the lower chloroplasts, could increase leaf photosynthesis rates 
much more than additional red or blue light (Terashima et al. 2009).

The relationship between red (R) and far-red (FR) light is an important factor for plants. Red and far-red light, and the R:FR ratio, regulate many processes throughout the life history of plants. Several studies have demonstrated that this relationship is important for germination, flowering, internode elongation, and bud outgrowth (Demotes-Mainarda et al. 2016). The light spectrum can be modified using spectrum conversion films or LEDs, or more conventional lighting that supplements natural light. These light supplements might facilitate a simultaneous increase in biomass, thereby improving the quality of plants. Thus, the light spectrum could be modified to obtain a higher R:FR ratio using plastic films that convert the least effective wavelengths for photosynthesis (Demotes-Mainarda et al. 2016).

\section{Plant responses to the wavelength and intensity of light}

The wavelength and intensity of light are important factors in the formation and accumulation of secondary metabolites. Light intensity influences the accumulation of capsaicinoids in hot peppers (Jeeatid et al. 2017). Specific secondary plant metabolites act as antioxidant protective pigments in plants. Although not synthesized by humans, these metabolites are taken up by our bodies in diets containing fruit and vegetables. Extensive studies show that the enhancement of specific wavelengths leads to changes in plants. UV-B radiation has regulatory effects on the secondary metabolism of plants. For example, light exerts a regulatory function on L-ascorbate (Vitamin C) levels in plants. Vitamin C increases with increasing irradiance, due to the stimulation of the D-mannose /L-galactose biosynthetic pathway. The physiological network for the regulation of vitamin $\mathrm{C}$ in plants by light involves both respiration and photosynthesis (Ntagkas et al. 2018). Higher R:FR ratios enhance vitamin $\mathrm{C}$ levels in the leaves of Phaseolus vulgaris. Blue light also promotes vitamin $\mathrm{C}$ synthesis in a variety of leafy vegetables. Consequently, the spectral distribution of light (R:FR ratio of 1.1 or pronounced blue fraction) enhances vitamin $\mathrm{C}$ synthesis. Thus, both visible and invisible light influence the growth and metabolism of plants. UV enhances vitamin $\mathrm{C}$ synthesis in soybean sprouts. Flavonoid biosynthesis genes are regulated by UV-B and flavonoids that accumulate in cellular compartments, including cell walls, vacuoles, and chloroplasts (Agati \& Tattini 2010).

Higher UV-B levels induce the biosynthesis of flavonoids and other important antioxidant properties, with UV-absorbing compounds acting as shielding components that reinforce photosynthesis and secondary metabolism (Burchard et al. 2000). In some orchards, apple trees are grown under spectral filters that alter the transmission of solar UV light. However, this approach delays the ripening of apples and reduces fruit size, as well as anthocyanin and flavonol content. Analysis of the gene expression of apples showed that their response to UV light changes at the gene level. Specifically, the transcription of flavonol synthase (FLS), ELONGATED HYPOCOTYL 5 (HY5), MYB10, and MYB22 is downregulated throughout fruit development under reduced UV (Henry-Kirk et al. 2017).

Carotenoids and chlorophylls form protein-pigmentcomplexes that function in the process of harvesting light for photosynthesis. Xanthophylls are a group of carotenoid compounds involved in light-dependent reactions and contribute to the photoprotection of photosystems. $\beta$-cryptoxanthin is also involved in lightdependent reactions (Ma et al. 2012). This compound is a major carotenoid in human blood that contributes towards preventing certain diseases, especially cancers, due to its antioxidative activity.

Ma et al. (2012) irradiated citrus fruits with blue $(470 \mathrm{~nm})$ and red $(660 \mathrm{~nm})$ light-emitting diode (LED) light. The authors showed that $\beta$-cryptoxanthin levels in citrus flavedo were increased by red light, but not affected by blue light. Another study showed that red LED influences the quality of citrus flavedo. Yamaga et al. (2016) reported that the $a^{*}$ value (red color) of the peel of satsuma mandarins exposed to red LED irradiation was 1.2 and 1.4 times higher than that of fruit subjected to dark treatment with 4-8 days of irradiation, respectively. Although red LED irradiation influenced the color of rind to a certain degree, it did not influence internal fruit quality. Thus, in some cases, modified light environments influence the quality of fruit, possibly controlling the growth of fruit under field conditions.

\section{Modifying the light environment affects plants under field conditions}

The flowering of photoperiod-sensitive plants is often controlled using incandescent lamps in greenhouses. These lamps have been recently replaced with LEDs (Morrow 2008). LEDs have a variety of applications in horticultural lighting. For instance, LEDs are used in environmental research under controlled conditions, for lighting tissue cultures, and as supplemental and photoperiod lighting for greenhouses. Unlike incandescent lamps, LED lighting systems have several unique advantages over existing horticultural lighting, 
including the ability to control spectral composition, and to produce very high light levels with low radiant heat output when cooled properly.

LED lighting systems are used to maintain light output for years without requiring replacement. LEDs are the first light source to have the capability of true spectral composition control, allowing wavelengths to be matched to plant photoreceptors, optimizing production, and influencing the morphology and composition of plants. LEDs are safer to operate than other types of lamps due to having no glass envelopes or high touch temperatures and containing no mercury. These systems have progressed from simple red-only LED arrays using the limited components available at the time, to high-density, multicolor LED chip-on-board devices. In addition, several studies have shown that the modification of spectral quality through colored shade nets acts as a physiological tool to modify the crop microenvironment, and to promote plant growth and yield (Ilić \& Fallik 2017). Ilić \& Fallik (2017) suggested that light quality influences the biosynthesis, accumulation, and retention of vegetable phytochemicals, as well as the onset of decay during storage. Thus, the modulation of light quality should be incorporated into the management practices of vegetable producers. The modification of light quality facilitates preservation of the freshness and post-harvest quality of vegetables for extended periods, thereby meeting consumer demands for vegetables of high nutritional value year-round.

Reflective mulching sheets provide a useful approach for modifying the light environment. Reflective sheets effectively increase the intensity of light within the crop canopy, thus improving fruit color in the shaded parts of crops. This phenomenon reduces the average percentage of noncommercial fruit without negatively affecting internal fruit quality, ultimately increasing the profits of growers. Several studies have shown the positive effects of reflective mulches on the quality and quantity of fruit. For instance, Ju et al. (1999) demonstrated how reflective films increase anthocyanin concentrations and reduce chlorophyll concentrations in 'Fuji' apples.

Covering reflective mulches affects the secondary metabolites in the aboveground and underground parts of plants. For example, turnip roots grown with blue mulch had high concentrations of total glucosinolates and ascorbic acid. Reducing-sugar concentrations were higher in roots grown with green mulches than with blue mulches. It is important to compare the chemical composition of roots from plants grown with blue versus green mulches, because the greatest differences are obtained with reflected blue mulches. Thus, blue light appears to influence the enzymes involved in the pathway transforming glucose into glucosinolate. The spectrum of light reflected from a mulch placed on the soil surface might influence the shoot/root biomass ratio and the

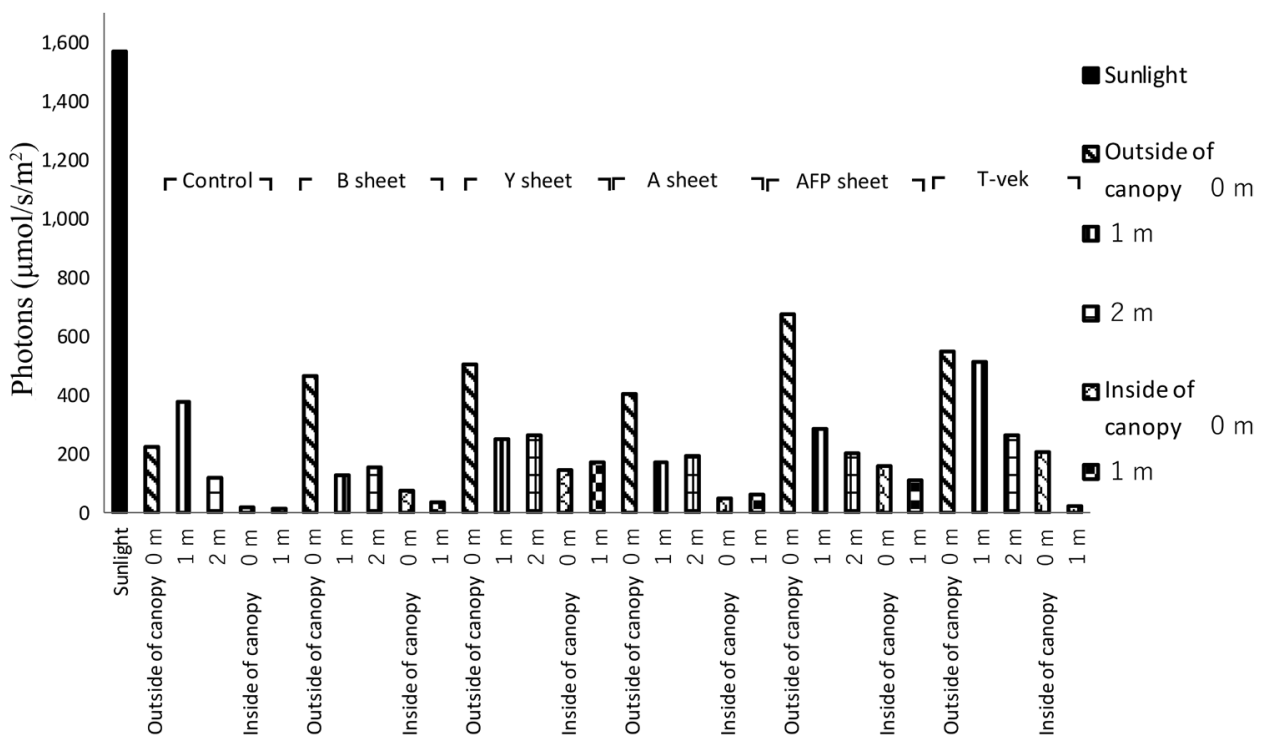

Fig. 1. Comparison of light reflected from bare ground (control) and different reflective mulching sheets $(420 \mathrm{~nm}-470 \mathrm{~nm}$ : B sheet, $520 \mathrm{~nm}-570 \mathrm{~nm}$ : Y sheet, $570 \mathrm{~nm}-620 \mathrm{~nm}$ : A sheet, and all wavelengths: AFP sheet, and Tyvek sheets) in a citrus (Satsuma mandarin/Ehime - Nakate) orchard located in Kagawa, Japan Light intensity (The photosynthetic photon flux density / PPFD) was measured at five fixed sites inside $(15 \mathrm{~cm} / 0 \mathrm{~m}$ and $1 \mathrm{~m}$ aboveground) and outside $(15 \mathrm{~cm} / 0 \mathrm{~m} 1 \mathrm{~m}$ and $2 \mathrm{~m}$ aboveground) of the tree crown in September at 10:00 to 14:00 (From Kuniga et al. 2013). 
Table 1. Insects captured by traps set above different types of mulch sheets ${ }^{\mathrm{Z}}$

\begin{tabular}{|c|c|c|c|c|c|c|c|c|c|c|}
\hline \multirow[b]{2}{*}{ Species } & \multicolumn{7}{|c|}{ Mulch Sheets } & \multicolumn{3}{|c|}{ ANOVA $^{Y}$} \\
\hline & Month & Control & B sheet & Y sheet & A sheet & AFP sheet & T-vek & Month & Sheet & $\begin{array}{l}\text { Month } \\
\times \text { Sheet }\end{array}$ \\
\hline \multirow[t]{3}{*}{ Total number } & July & $119.06^{\mathrm{ax}}$ & $67.37^{b}$ & $67.03^{b c}$ & $67.53 \mathrm{bc}$ & $45.30^{c}$ & $49.03^{c}$ & & & \\
\hline & Aug. & $224.06^{\mathrm{a}}$ & $127.80^{\mathrm{ab}}$ & $92.37^{\mathrm{b}}$ & $113.50^{\mathrm{b}}$ & $73.43^{\mathrm{b}}$ & $69.57^{\mathrm{b}}$ & $* *$ & $* *$ & $* *$ \\
\hline & Sept. & $287.94^{\mathrm{a}}$ & $227.80^{\mathrm{ab}}$ & $278.97^{\text {a }}$ & $249.47 \mathrm{ab}$ & $195.47^{\mathrm{c}}$ & $172.57^{\mathrm{c}}$ & & & \\
\hline \multirow[t]{3}{*}{ Thysanoptera (Thrip) } & July & $7.00^{\mathrm{a}}$ & $5.58^{\mathrm{a}}$ & $4.28^{\mathrm{a}}$ & $3.70^{\mathrm{a}}$ & $1.00^{\mathrm{a}}$ & $4.23^{\mathrm{a}}$ & & & \\
\hline & Aug. & $16.06^{\mathrm{a}}$ & $5.81^{\mathrm{a}}$ & $6.76^{\mathrm{a}}$ & $12.40^{\mathrm{a}}$ & $9.83^{\mathrm{a}}$ & $5.40^{\mathrm{b}}$ & $* *$ & $* *$ & $* *$ \\
\hline & Sept. & $3.22^{\mathrm{a}}$ & $3.23^{\mathrm{a}}$ & $4.17^{\mathrm{a}}$ & $2.83^{\mathrm{a}}$ & $1.63^{\mathrm{b}}$ & $1.77^{\mathrm{b}}$ & & & \\
\hline \multirow[t]{3}{*}{ Hemiptera (Pentatomidae) } & July & $8.83^{\mathrm{a}}$ & $8.60^{\mathrm{ac}}$ & $8.63^{\mathrm{b}}$ & $6.97 \mathrm{ac}$ & $5.67^{\mathrm{c}}$ & $4.80^{\mathrm{c}}$ & & & \\
\hline & Aug. & $14.78^{a b c}$ & $25.47^{\mathrm{a}}$ & $15.50^{\mathrm{ab}}$ & $22.13 \mathrm{abc}$ & $9.10^{\mathrm{c}}$ & $10.43^{c}$ & * & $* *$ & n.s. \\
\hline & Sept. & $28.33^{\mathrm{b}}$ & $37.07^{b}$ & $36.93^{\mathrm{a}}$ & $34.70^{\mathrm{b}}$ & $36.50^{\mathrm{b}}$ & $30.80^{\mathrm{b}}$ & & & \\
\hline \multirow[t]{3}{*}{ Hemiptera (Leafhopper) } & July & $7.94^{\mathrm{a}}$ & $2.50^{\mathrm{b}}$ & $5.60^{\mathrm{ab}}$ & $3.53^{\mathrm{b}}$ & $3.60^{\mathrm{b}}$ & $3.40^{\mathrm{b}}$ & & & \\
\hline & Aug. & $2.61^{\mathrm{b}}$ & $1.50^{\mathrm{b}}$ & $3.00^{\mathrm{a}}$ & $1.10^{\mathrm{b}}$ & $1.00^{\mathrm{b}}$ & $0.93^{b}$ & $* *$ & $* *$ & $* *$ \\
\hline & Sept. & $4.72^{b}$ & $2.30^{\mathrm{b}}$ & $8.17^{\mathrm{a}}$ & $4.57^{\mathrm{b}}$ & $3.23^{\mathrm{b}}$ & $2.63^{b}$ & & & \\
\hline \multirow[t]{3}{*}{ Hemiptera (Aphid) } & July & $13.61^{\mathrm{a}}$ & $8.06^{\mathrm{a}}$ & $9.45^{\mathrm{a}}$ & $13.63^{\mathrm{a}}$ & $4.70^{\mathrm{a}}$ & $5.37^{\mathrm{a}}$ & & & \\
\hline & Aug. & $80.00^{\text {a }}$ & $42.35^{a b}$ & $13.14^{\mathrm{ab}}$ & $17.83^{\mathrm{ab}}$ & $9.53^{a b}$ & $9.17^{\mathrm{b}}$ & $* *$ & $* *$ & $* *$ \\
\hline & Sept. & $17.83^{\mathrm{a}}$ & $16.39^{\mathrm{a}}$ & $7.69^{a b}$ & $10.73^{\mathrm{a}}$ & $7.00^{a b}$ & $6.57^{\mathrm{b}}$ & & & \\
\hline \multirow[t]{3}{*}{ Lepidoptera (Moth, Butterfly) } & July & $1.44^{\mathrm{a}}$ & $0.77^{\text {a }}$ & $1.53^{\mathrm{a}}$ & $1.27^{\mathrm{a}}$ & $1.13^{\mathrm{a}}$ & $1.33^{\mathrm{a}}$ & & & \\
\hline & Aug. & $6.72^{\mathrm{a}}$ & $5.17 \mathrm{ab}$ & $4.93 \mathrm{abc}$ & $2.87^{\mathrm{c}}$ & $3.13^{c}$ & $3.27 \mathrm{abc}$ & $*$ & $* *$ & n.s. \\
\hline & Sept. & $5.83^{\mathrm{a}}$ & $5.67^{\mathrm{a}}$ & $4.57^{\mathrm{a}}$ & $5.00^{\mathrm{a}}$ & $3.37^{\mathrm{a}}$ & $3.67^{\mathrm{a}}$ & & & \\
\hline \multirow[t]{3}{*}{ Diptera (Fly) } & July & $11.78^{a}$ & $8.43^{\mathrm{a}}$ & $7.63^{a b}$ & $7.50^{b c}$ & $5.43^{c}$ & $7.67^{\mathrm{c}}$ & & & \\
\hline & Aug. & $16.89^{\mathrm{a}}$ & $7.93^{b c}$ & $8.60^{\mathrm{bc}}$ & $12.10^{\mathrm{ab}}$ & $10.23^{\mathrm{abc}}$ & $5.97^{\mathrm{c}}$ & $* *$ & $* *$ & $* *$ \\
\hline & Sept. & $40.78^{a b}$ & $46.40^{\mathrm{a}}$ & $34.80^{\mathrm{ab}}$ & $31.63 \mathrm{bc}$ & $26.27^{b c}$ & $29.70^{\mathrm{bc}}$ & & & \\
\hline \multirow[t]{3}{*}{ Diptera (Mosquito) } & July & $5.22^{\mathrm{ab}}$ & $6.43^{\mathrm{a}}$ & $4.77^{a b}$ & $5.13^{\mathrm{ab}}$ & $4.27^{\mathrm{ab}}$ & $3.40^{\mathrm{b}}$ & & & \\
\hline & Aug. & $3.06^{\mathrm{ab}}$ & $4.43^{\mathrm{a}}$ & $2.90^{\mathrm{ab}}$ & $3.27 \mathrm{ab}$ & $3.30^{\mathrm{ab}}$ & $2.47^{\mathrm{b}}$ & $* *$ & $* *$ & $* *$ \\
\hline & Sept. & $61.83^{\mathrm{b}}$ & $42.77^{c}$ & $81.00^{\mathrm{a}}$ & $75.87^{\mathrm{a}}$ & $47.40^{\mathrm{c}}$ & $37.10^{\mathrm{c}}$ & & & \\
\hline \multirow[t]{3}{*}{ Coleoptera (Beetle) } & July & $3.50^{\mathrm{a}}$ & $1.87^{\mathrm{b}}$ & $2.20^{\mathrm{ab}}$ & $2.07^{\mathrm{ab}}$ & $1.53^{\mathrm{b}}$ & $1.53^{\mathrm{b}}$ & & & \\
\hline & Aug. & $6.89^{\mathrm{a}}$ & $2.67^{\mathrm{c}}$ & $4.17^{\mathrm{a}}$ & $2.60^{c}$ & $3.17 \mathrm{bc}$ & $3.80 \mathrm{bc}$ & $* *$ & $* *$ & n.s. \\
\hline & Sept. & $4.06^{\mathrm{ab}}$ & $3.37^{\mathrm{ab}}$ & $4.93^{\mathrm{a}}$ & $3.37^{\mathrm{ab}}$ & $2.03^{b}$ & $2.03^{b}$ & & & \\
\hline \multirow[t]{3}{*}{ Hymenoptera (Wasp, Bee) } & July & $55.50^{\mathrm{a}}$ & $21.40^{\mathrm{b}}$ & $20.93^{\mathrm{bc}}$ & $20.63^{b}$ & $12.67^{\mathrm{c}}$ & $15.43^{\mathrm{c}}$ & & & \\
\hline & Aug. & $74.44^{\mathrm{a}}$ & $29.27^{b c}$ & $31.37^{b c}$ & $36.20^{\mathrm{b}}$ & $21.87^{\mathrm{c}}$ & $22.60^{\mathrm{c}}$ & $* *$ & $* *$ & n.s. \\
\hline & Sept. & $114.61^{\mathrm{a}}$ & $64.97^{b c}$ & $90.63^{\mathrm{b}}$ & $75.50 \mathrm{bc}$ & $62.63^{\mathrm{c}}$ & $53.10^{\mathrm{c}}$ & & & \\
\hline \multirow[t]{3}{*}{ Araneae (Spider) } & July & $3.11^{\mathrm{a}}$ & $2.63^{\mathrm{a}}$ & $2.03^{\mathrm{a}}$ & $2.33^{\mathrm{a}}$ & $1.90^{\mathrm{a}}$ & $2.27^{\mathrm{a}}$ & & & \\
\hline & Aug. & $1.72^{\mathrm{a}}$ & $1.00^{\mathrm{a}}$ & $1.00^{\mathrm{a}}$ & $1.43^{\mathrm{a}}$ & $1.43^{\mathrm{a}}$ & $1.33^{\mathrm{a}}$ & n.s. & $* *$ & n.s. \\
\hline & Sept. & $6.44^{\mathrm{a}}$ & $4.73^{\mathrm{a}}$ & $5.47^{\mathrm{a}}$ & $5.00^{\mathrm{a}}$ & $5.17^{\mathrm{a}}$ & $4.90^{\mathrm{a}}$ & & & \\
\hline \multirow[t]{3}{*}{ Acari (mite) } & July & $0.72^{\mathrm{a}}$ & $0.37^{\mathrm{a}}$ & $0.20^{\mathrm{a}}$ & $0.60^{\mathrm{a}}$ & $0.23^{\mathrm{a}}$ & $0.40^{\mathrm{a}}$ & & & \\
\hline & Aug. & $0.89^{\mathrm{a}}$ & $1.07^{\mathrm{a}}$ & $0.90^{\mathrm{a}}$ & $1.53^{\mathrm{a}}$ & $0.67^{\mathrm{a}}$ & $4.13^{\mathrm{a}}$ & n.s. & $* *$ & n.s. \\
\hline & Sept. & $0.11^{\mathrm{a}}$ & $0.27^{\mathrm{a}}$ & $0.10^{\mathrm{a}}$ & $0.20^{\mathrm{a}}$ & $0.10^{\mathrm{a}}$ & $0.17^{\mathrm{a}}$ & & & \\
\hline
\end{tabular}

${ }^{\mathrm{Z}}$ Numbers of insects per trap

${ }^{*}{ }^{* *}, P<0.01 ; *, P<0.05 ; \mathrm{NS}, P>0.05$

${ }^{x}$ Different letters above the table indicate significant differences $(P<0.05)$ evaluated by Steel-Dwass' test Insects were trapped in yellow sticky traps $(21 \mathrm{~cm} \times 30 \mathrm{~cm})$ that were placed monthly (July to September) for 7 days. Traps were attached to one citrus tree and placed beside the south and north sides of the tree crown, and $1 \mathrm{~m}$ aboveground (From Kuniga et al. 2016). 
flavor-related chemical composition of field-grown crop plants for food (Antonious et al. 1996). Arabidopsis preferentially allocate glucosinolates in the periphery of leaves, possibly as a defense mechanism against feeding by chewing herbivores that frequently approach leaves from the edge (Shroff et al. 2008).

Other studies have suggested that reflective sheet mulching influences the migratory flight paths of insects to orchards (Frank \& Liburd 2005, Roberts \& Paul 2006, Mishiro et al. 2009). Mishiro et al. (2009) demonstrated how reflective sheet mulching influences the flight behavior of fruit-sucking stink bugs-Plautia crossota stali and Glaucias subpunctatus. Fewer stink bugs were captured in the mulched plots compared with uncovered plots. Furthermore, many stink bugs found on the sheets could not fly. Thus, the reflective material disturbed the flight behavior of stink bugs, with this influence being greater on P. c. stali than on G. subpunctatus. Therefore, the reflective light from mulch directly influences insect herbivores.

Kuniga et al. (2013) compared the effects of bare ground (control) and different reflective mulching sheets (420 nm-470 nm, $520 \mathrm{~nm}-570 \mathrm{~nm}, 570 \mathrm{~nm}-620 \mathrm{~nm}$, all wavelengths, and Tyvek sheets) on the light environment and insect flight in a citrus orchard (Satsuma mandarin/ Ehime - Nakate) from July to September. The authors showed that Tyvek sheets were associated with the greatest quantity of reflective light at $1 \mathrm{~m}$ above the ground, outside the tree crown. Light quantity was reduced in the crown over the bare ground, and the level of light at $0 \mathrm{~m}$ and $1 \mathrm{~m}$ aboveground increased when mulching sheets were used (Fig. 1).

Another study showed that the type of mulching sheets used altered the number of insects captured in sticky traps placed in each treatment area, as well as the populations of flying insects and species (orders). Moreover, twice as many insects was captured over bare ground as compared with over certain reflective mulching sheets $(420 \mathrm{~nm}-470 \mathrm{~nm}, 520 \mathrm{~nm}-570 \mathrm{~nm}$, and $570 \mathrm{~nm}-620$ $\mathrm{nm})$. Significantly fewer individuals of certain species of insects were trapped at all wavelengths and over Tyvek mulching sheets as compared with bare ground. Thus, the use of mulching sheets in citrus orchards changes the profile of the light environment both inside and outside tree crowns. Furthermore, the flight ability and populations of insects are altered by different types of ground cover (Kuniga et al. 2016) (Table 1). In a two-year study, Frank \& Liburd (2005) demonstrated variation in the effectiveness of mulches for controlling the number of immature silverleaf whitefly and aphids, along with the incidence squash silverleaf disorder. The authors concluded that this phenomenon might be a function of the difference in population pressure caused by environmental conditions. For instance, previous studies have showed that silverleaf whitefly are attracted to yellow colors in the visible light spectra. Therefore, the flight behavior of insects responds to multiple factors.

\section{Conclusions and future directions}

The importance of light for the growth of plants derives from its contribution to the synthesis of carbons, including sugars, starches, and pigments. Plant cells have evolved the ability to perceive light as an essential process in the development of functional signaling between plant organs. The light environment also influences the presence and activity of insects, molds, and bacteria. Therefore, it is important to modify the light environment in fields to enhance the productivity and quantity of horticultural crops by using artificial light, hail nets, and sheets.

\section{Acknowledgement}

This research was supported by the special scheme project on vitalizing management entities of agriculture.

\section{References}

Agati, G. \& Tattini, M. (2010) Multiple functional roles of flavonoids in photoprotection. New Phytologist, 186, 786-793.

Antonious, G. F. et al. (1996) Light reflected from colored mulches to growing turnip leaves affects glucosinolate and sugar contents of edible roots. Photochemistry and Photobiology, 64, 605-610.

Bonachela, S. et al. (2012) How plastic mulches affect the thermal and radiative microclimate in an unheated lowcost greenhouse. Agricultural and Forest Meteorology, 152, 65-72.

Burchard, P. et al. (2000) Contribution of hydroxycinnamates and flavonoids to epidermal shielding of UV-A and UV-B radiation in developing rye primary leaves as assessed by ultraviolet -induced chlorophyll fluorescence measurements. Plant, Cell and Environment, 23, 1373-1380.

Christians, M. J. et al. (2018) Light regulates the RUBylation levels of individual cullin proteins in Arabidopsis thaliana. Plant Molecular Biology Reporter, 36, 123-134.

Decoteau, D. R. et al. (1988) Plastic mulch color effects on reflected light and tomato plant growth. Scientia Horticulturae, 34, 169-175.

Demotes-Mainard, S. et al. (2016) Plant responses to red and far-red lights, applications in horticulture. Environmental and Experimental Botany, 121, 4-21.

Folta, K. M. \& Carvalho, S. D. (2015) Photoreceptors and control of horticultural plant traits. HortScience, 50, $1274-1280$.

Frank, D. L. \& Liburd, O. E. (2005) Effects of living and 
synthetic mulch on the population dynamics of whiteflies and aphids, their associated natural enemies, and insecttransmitted plant diseases in zucchini. Entomological Society of America, 34, 857-865.

Gross, M. (2015) Twenty-five years of climate change failure. Current Biology, 25, R301-R327.

Henry-Kirk, R. A. et al. (2018) Solar UV light regulates flavonoid metabolism in apple (Malus $x$ domestica). Plant Cell \& Environment, 41, 675-688.

Iglesias, I. \& Alegre, S. (2009) The effects of reflective film on fruit color, quality, canopy light distribution, and profitability of 'Mondial Gala' apples. HortTechnology, 19, 488-498.

Ilić, Z. S. \& Fallik, E. (2017) Light quality manipulation improves vegetable quality at harvest and postharvest. Environmental and Experimental Botany, 139, 79-90.

Jeeatid, N. et al. (2017) Light intensity affects capsaicinoids accumulation in hot pepper (Capsicum chinense Jacq.) cultivars. Horticulture Environment \& Biotechnology, 58, 103-110.

Ju, Z. et al. (1999) Effects of covering the orchard floor with reflecting films on pigment accumulation and fruit coloration in 'Fuji' apples. Scientia Horticulturae, 82, 47-56.

Kami, C. et al. (2012) Nuclear phytochrome a signaling promotes phototropism in Arabidopsis. The Plant Cell, 24, 566-576.

Kuniga, T. et al. (2013) Some characteristics in several kinds of mulch sheets affect environment of fields. Kinki Chuugoku Shikoku Nougyoukenkyu (Kinki Chungoku Shikoku Agricultural Research), 22, 17-20 [In Japanese with English summary].

Kuniga, T. et al. (2016) Effects of reflective mulching sheets to light environment and flight of insects in citrus orchards. JSATM (Journal of Japanese Society of Agricultural Technology Management), 23, 9-14.

Layne, D. R. et al. (2001) Tree fruit reflective film improves red skin coloration and advances maturity in peach. HortTechnology, 11, 234-242.

Ma, G. et al. (2012) Effect of blue and red LED light irradiation on $\beta$-cryptoxanthin accumulation in the flavedo of citrus fruits. Journal of Agricultural and Food Chemistry, 60, 197-201.

Mishiro, K. et al. (2009) Effect of reflective sheet mulching on migratory flight to citrus orchard in two stinkbugs, Plautia crossota stali and Glaucias subpunctatus. Bulletin of the National Institute of Fruit Tree Science, 9, 23-30.

Morinaga, K. et al. (2010) Development of drip irrigation and liquid fertigation system with plastic mulching and its extension for citrus fruit production. Engeigakukenkyu (Hort. Res.), 9, 129-135 [In Japanese with English summary].

Morrow, R. C. (2008) LED Lighting in horticulture. HortScience, 43, 1947-1950.

Ntagkas, N. et al. (2018) Light regulates ascorbate in plants: An integrated view on physiology and biochemistry. Environmental and Experimental Botany, 147, 271-280.

Roberts, M. R. \& Paul, N. D. (2006) Seduced by the dark side: integrating molecular and ecological perspectives on the influence of light on plant defense against pests and pathogens. New Phytologist, 170, 677-699.

Rosenzweig, C. et al. (2014) Assessing agricultural risks of climate change in the 21 st century in a global gridded crop model inter-comparison. Proceedings of the National Academy of Sciences of the USA, 111, 3268-3273.

Shimazaki, M. \& Nesumi, H. (2016) A method for high-quality citrus production using drip fertigation and plastic sheet mulching. JARQ, 50, 301-306.

Shroff, R. et al. (2008) Nonuniform distribution of glucosinolates in Arabidopsis thaliana leaves has important consequences for plant defense. Proceedings of the National Academy of Sciences of the USA, 105, 6196-6201.

Spalding, E. P. (2003) Light signaling. Plant Physiology, 133, 1417-1419.

Terashima, I. et al. (2009) Green light drives leaf photosynthesis more efficiently than red light in strong white light: revisiting the enigmatic question of why leaves are green. Plant Cell Physiology, 50, 684-697.

Yamaga, I. et al. (2016) Rind color development in satsuma mandarin fruits treated by low-intensity red light-emitting diode (LED) irradiation. Food Science and Technology Research, 22, 59-64.

Zandalinas, S. I. et al. (2018) Plant adaptations to the combination of drought and high temperatures. Physiologia Plantarum, 162, 2-12.

Zhang, T. et al. (2011) Green light induces shade avoidance symptoms. Plant Physiology, 157, 1528-1536.

Zhang, T. et al. (2018) Effects of different LED sources on the growth and nitrogen metabolism of lettuce. Plant Cell, Tissue and Organ Culture, 134, 231-240. 